\title{
DO FIRM-BANK RELATIONSHIPS AFFECT CORPORATE CASH HOLDINGS?
}

\author{
Andriy Tsapin \\ National Bank of Ukraine \\ National University of Ostroh Academy \\ Email: Andriy.Tsapin@bank.gov.ua
}

\begin{abstract}
This paper explores the impact of firm-bank relationships on corporate cash holdings using a sample of more than 4,000 Ukrainian companies over the period from 2008 to 2015. The empirical evidence suggests that the duration of the relationship and the presence of multiple bank relationships affect corporate cash holdings. Specifically, an increase in the length of a bank's relationship with a main bank initially reduces corporate cash holdings but the effect turns positive due to the hold-up problem when the relationship matures. We also observe that companies with a greater number of bank relationships tend to hold more cash reserves, whereas more competition among banks allows firms to hold less cash. Additionally, we document that firmbank relationships are important in helping firms resolve agency conflicts and facilitate reducing a firm's financial constraints.
\end{abstract}

\section{JEL Codes: G32, G21, D22}

\section{Keywords: cash holdings, firm-bank relationships, financial constraints, managerial discretion}

\section{INTRODUCTION}

After the 2008 crisis, financial and economic literature began scrutinizing corporate liquidity management decision to explain a significant increase in corporate cash reserves. The literature documents an accumulation of excess cash by firms that were expecting uncertainty about future cash flows (Almeida, Campello \& Weisbach, 2004; Han \& Qiu, 2007), expecting financial constraints (Opler, Pinkowitz \& Williamson, 1999; Bigelli \& Sanchez-Vidal, 2012), or facing agency-type conflicts (Yafeh \& Yosha, 2003; Yu, Sopranzetti \& Lee, 2015). At least theoretically, a bank's influence can weaken the effect of those issues that lead to excess cash holdings. Specifically, a close relationship between a company and a bank can ease a company's financial constraints (Ioannidou \& Ongena, 2006). Banks also can assist firms in resolving agency conflicts (Yafeh \& Yosha, 2003).

Redundant liquidity is especially a concern in emerging markets where firms rely more on internally generated funds because of the cost of external financing (Al-Najjar, 2013). In emerging markets, (i) firms typically do not have long-term credit histories and established market reputations (Singh, 2003); (ii) firms are susceptible to shocks in the banking sector because underdeveloped capital markets restrict firms from raising external capital and do not offer acceptable substitutes for bank loans (Shen \& Huang, 2003). Furthermore, emerging markets typically have weak corporate governance standards and limited information disclosure requirements, which yields an information gap between a firm's managers and investors (Uyar \& Kuzey, 2014). Thus, firms may be inclined to hoard more cash to finance operations than developed market peers. In addition, since emerging market financial systems are bank-oriented, corporate decisions on cash holdings are expected to be sensitive to firm-bank relationships.

Research on a bank's influence on corporate cash holdings is rarely conducted even in developed countries because of data limitations (Ozkan \& Ozkan, 2004). Recently, Yu, Sopranzetti \& Lee (2015) and Uyar \& Kuzey (2014) studied the determinants of corporate cash holdings in emerging markets. Yu, Sopranzetti \& Lee (2015) focused on the role of banking relationships as a governance device in corporate decisions on the cash ratio. However, to our knowledge, no research has been conducted on the nonlinearity in a bank's impact on corporate cash holdings.

This paper explores whether firm-bank relationships influence corporate cash holdings in an emerging market. In this study, we examine the role of the duration of the relationship with a main bank and ties to multiple banks in decisions relating to corporate cash holdings. Specifically, we test whether the effect of the duration on corporate cash holdings is nonlinear and if it turns from negative to positive in a mature relationship because of the hold-up problem. We also examine whether numerous banking relationships can increase corporate cash holdings because of free-rider monitoring problems or if they enable a reduction of cash by a bank's clients thanks to competition among banks. 
Our study explores the specific drivers of cash holdings for a comprehensive sample of Ukrainian exporter companies over the period from 2008 to 2015. Ukraine is an excellent market for researching the link between corporate cash flows and banking relationships for several equally important reasons. First, Ukraine is an emerging market where constrained firms have no acceptable substitutes for bank financing. Second, since Ukrainian exports accounted for almost 50\% of GDP in 2015, unpredictable external conditions and export price volatility make the Ukrainian economy vulnerable to external shocks. Sensitivity to external shocks can be an important determinant of cash holdings, which explains our choice of a sample of large Ukrainian exporters. Finally, the National Bank of Ukraine (NBU) reports that economic agents keep a large share of assets in liquid instruments to ensure a proper liquidity buffer against possible shocks (NBU, 2016). At the same time, the excess liquidity does not notably affect bank lending (does not encourage a credit recovery) due to the poor creditworthiness of borrowers or inappropriate firm-bank links. We believe this study can help identify the specific determinants of cash holdings and reveal the role banking relationships play in corporate liquidity management.

The next section reviews relevant theories and introduces hypotheses on the link between corporate cash holdings and bank relationships. Section 3 describes the empirical methodology used; section 4 discusses the data sets and provides description statistics; section 5 presents the empirical results; and section 6 concludes.

\section{THEORY AND EMPIRICAL HYPOTHESES}

The financial literature on the topic traditionally use trade-off and pecking order theories to explain corporate cash levels. The trade-off approach argues that firms optimize the level of cash by weighing the marginal costs and benefits of cash (Miller \& Orr, 1966). According to Keynes (1936), the benefits of those holdings stem from transactional and precautionary motives. Cash allows firms to avoid liquidating assets and to invest when financial constraints are met. Additionally, cash reduces the cost of external funds.

The pecking order model rejects the notion of a target level for liquid assets and says that firms finance themselves in a hierarchical fashion based on the relative costs of different sources of funds: firms first rely on internal financial funds and then external financing (Myers \& Majluf, 1984). In this model, cash is considered as a buffer between retained earnings and investments.

Agency cost can also explain variations in cash reserves. The interests of a firm's managers and its shareholders are not perfectly aligned, and conflicts of interest over payout policies can arise (Jensen, 1986). Managers tend to increase the amount of assets under their control (i.e. cash or equivalents), thereby increasing their own power. Entrenched managers can even be inclined to invest free cash flows at below the cost of capital or spend funds inefficiently. Their behavior (managerial discretion) causes overinvestment and should be relevant for firms without substantial investment opportunities.

Companies can hoard cash in response to adverse shocks and in the face of financial constraints (Almeida, Campello \& Weisbach, 2004) or as a result of managerial moral hazard (Yafeh \& Yosha, 2003). Notably, firm-bank relationships can affect both of those issues (Degryse \& de Jong, 2006).

When firms form new banking relationships, they secure higher loan amounts and expand their access to capital market services (Gopalan, Udell \& Yerramilli, 2011). Moreover, Petersen \& Rajan (1994) and Berger \& Udell (1995) offer evidence that firms with longer relationships have easier access to bank credit and pay lower interest rates. Long-term bank relationships are most beneficial for firms that are sensitive to hold-up problems and suffer from large information asymmetries. ${ }^{1}$ Luo \& Hachiya (2005) find that cash is less important for firms with closer bank relations. It is plausible that a firm could be interested in building a long-term relationship with a bank and then holding less cash once it secures a good credit standing. ${ }^{2}$

However, firm-bank relationships can also impose costs and become costly over time. In establishing a relationship with a firm, banks can acquire access to information not otherwise publicly available (Fama, 1985). A bank that collects private corporate information gains bargaining power over the client (Rajan, 1992). In such a case, the firm faces a hold-up cost and can be forced by the bank to pay higher financing costs or to maintain additional cash holdings. Pinkowitz \& Williamson (2001) find that firms tend to hold more cash during periods of high bank power (when banks abuse their monopolistic power). We thus offer our first hypothesis:

Hypothesis 1: An increase in the duration of a relationship between a firm and its main bank initially has a negative effect on corporate cash holdings, but the effect turns positive at a certain level.

A firm can easily be captured by its main bank owing to hold-up cost if the firm does business with a single bank (Rajan, 1992). The firm-bank relationship with a bank becomes less valuable if a bank's borrowing constraints outweigh the information benefits

\footnotetext{
${ }^{1}$ Von Thadden (2004) discusses the "hold-up problem" in detail.

${ }^{2}$ Here we focus on the key role of a main bank because the main bank is typically responsible for screening and monitoring the firm (Sufi, 2007).
} 
(Gopalan, Udell \& Yerramilli, 2011). Working with multiple banks and spurring competition among creditors can eliminate the hold-up risk inherent in a single-bank relationship (Detragiache, Garella \& Guiso, 2000).

This can lead a firm to switch its main bank. The length of a banking relationship actually depends on determinants of switching costs, but firms are restrained from breaking existing relationships because switching may entail (i) additional transaction costs when opening new accounts, (ii) uncertainty about the quality of the new bank, and (iii) unobserved costs related to the loss of the capitalized value of the previously established relationship (Klemperer, 1995; Sharpe, 1990; Kim, Kliger, \& Vale, 2003). Moreover, after changing banks, a firm does gain additional access to bank financing from the new bank, but they pay a higher interest rate that deteriorates the firm's performance (Stephan, Tsapin \& Talavera, 2012). Therefore, a firm can better mitigate its dependence on its main bank by attracting a new niche bank or other financial institution (creditor) that can compete with the main bank.

However, there is no consensus in the literature regarding the link between the number of banks servicing a firm and a client's cash holdings. Firms can use new niche banks or banks that are prepared to finance a higher-risk firm's growth when an existing main bank has a resource limitation and declines to lend. Gopalan, Udell \& Yerramilli (2011) explain firms' desire to attract a new bank by the life cycle of the firms and their need for growth, which cannot be financed by their main bank. In this case, we should observe an increase in transaction costs and cash holdings for firms that work with several banks. Furthermore, Degryse \& Ongena (2001) argue that firms that work with many banks signal their low creditworthiness and are restricted in their access to external financing and thus should accumulate more cash. Finally, Chan, Lin, Chang \& Liao (2013) show that numerous bank relationships can drive firms to take higher risks under conditions of information asymmetry between banks and firms. Risky activities in turn are likely to be secured by an additional cash buffer.

The positive association between the number of banks and corporate cash holdings can also be explained by bank behavior. Specifically, multiple creditors can suffer from a mutual free-riding problem (Holmstrom, 1982; Bris \& Welch, 2005). The freerider problem arises when the moral hazard in banking deteriorates the quality of a bank's screening and monitoring activities, which results in costly financing for clients. Banks lose their motivation to lend because profits from mutually financed projects are shared with other creditors.

By contrast, Diamond (1991) argues that multiple bank relationships may decrease a firm's liquidity risk. Yu, Sopranzetti \& Lee (2015) document a negative association between a greater number of bank relationships and the level of cash holdings. They attribute this relationship to the lower needs of firms with multiple relationships to hold cash because they are likely to be less constrained in their access to external financing. Carletti, Cerasi \& Daltung (2007) point out that multiple bank relationships can positively influence overall monitoring and increase a firm's performance. They argue that sharing the burden of lending allows banks to diversify risk despite the free-riding that reduces the cost of financing.

Thus, if a greater number of bank relationships lead to increased transaction costs or force firms into riskier behavior, then firms are expected to hold more cash reserves as a contingency. However, if competition among banks facilitates access to capital, then firms tend to hold less cash. We thus offer our second hypothesis:

Hypothesis 2: The number of bank relationships has a positive effect on corporate cash holdings, but the effect turns negative at a certain level.

To summarize, this study tests the impact of firm-bank relationships on corporate cash holdings. Specifically, we focus on the non-linear effects of the length of firm-bank ties and multiple bank relationships. In particular, corporate cash reserves are hypothesized to decrease with the duration of a relationship with a main bank, while the hold-up problem derived from the main bank's information monopoly may push firms to accumulate cash. We also examine whether multiple bank relationships lead to a higher cash ratio and whether competition among banks or the possible diversification from multiple bank relationships are likely to reduce corporate cash holdings.

\section{REGRESSION MODEL}

We extend the empirical model established by Opler, Pinkowitz \& Williamson (1999) that includes fundamental determinants of cash holdings and build a regression model with the key characteristics of firm-bank relationships.

$$
\text { Cash }_{i t}=\beta_{1} \text { Duration }_{i t}+\beta_{2} \text { Duration }_{i t}^{2}+\beta_{3} N B_{i t}+\beta_{4} N B_{i t}^{2}+\sum_{j=5}^{13} \beta_{j} \text { Controls }_{i t}+\mu_{i}+\lambda_{i}+\tau_{t}+\varepsilon_{i t^{\prime}}
$$

where $i$ refers to firms and t to periods, $\mu_{i}, \lambda_{i}$ and $\tau_{t}$ are firm, industry, and time effects, respectively, $\varepsilon_{i t}$ denotes the error term. Cash is the ratio of cash to net assets. ${ }^{3}$ Duration $_{i t}$ is the duration of a relationship with a main bank. NB denotes the number of bank relationships.

\footnotetext{
${ }^{3}$ Net assets are defined as total assets excluding cash.
} 
The model (1) allows us to test the non-linear impact of firm-bank relationships on corporate cash holdings. In contrast to the linear framework where a constant effect can be detected, the nonlinearity in the regressions - the inclusion of higher ordered terms (Duration ${ }_{i t}^{2}$ and $N B_{i t}^{2}$ ) - allow the effects for duration and multiple bank relationships to vary with the value of the respective variables.

In our regression analysis, we control for other determinants of corporate cash holdings: the control variables are Cash Flow (CF), Net Working Capital (NWC), Size (Size), Leverage (Leverage), Debt Maturity (DM), and a proxy for the type of monetary policy (MP).

\section{Cash Flow}

The trade-off theory posits that cash is inversely related to cash flow because cash flow reduces the need for cash reserves (Kim, Mauer \& Sherman, 1998). The alternative view posits that firms that generate cash flow can conserve an amount of cash to fund investment in the event of financial constraints (Opler, Pinkowitz \& Williamson, 1999). The latter view, based on the pecking order theory, has more supporting empirical evidence.

\section{Net Working Capital}

Non-cash liquid assets or net working capital can substitute cash relatively easily (Opler, Pinkowitz \& Williamson, 1999). Firms should therefore hold less cash if they hold more net working capital.

\section{Size}

Larger firms are more transparent and diversified, have better credit history, and more collateral. Moreover, borrowing costs are not proportional to loan size, which allows larger firms to save transaction costs by using economies of scale (Miller \& Orr, 1966). Therefore, larger companies can more easily secure lower-cost external financing and should thus maintain lower cash holdings.

\section{Growth Opportunities}

Firms with growth opportunities suffer more from information asymmetry when applying for external capital. Therefore, they should hold more cash to avoid missing investment opportunities (Dittmar, Mahrt-Smith \& Servaes, 2003).

Leverage

Highly leveraged firms are more likely to experience financial distress and firms keep more cash as a reserve for this (Ferreira \& Vilela, 2003). However, leverage can also exert a negative influence on cash as it reduces the free cash flow problem (Harford, Klasa \& Maxwell, 2014).

\section{Debt Maturity}

Firms with a larger proportion of short-term debt should hold more cash as they have a greater need to renegotiate their debt and are more exposed to refinancing risk (Wu, Rui \& Wu, 2012).

\section{Bank Loans}

Dell'Ariccia \& Marquez (2004) argue that banks may insure borrowers against credit rationing. Bank loans and the related monitoring activity allow firms to mitigate asymmetric information between potential borrowers and their creditors, which eases a firm's financial constraints. Additionally, bank debt is an important tool for external corporate governance; it reduces managerial discretion as monitoring activity informs banks and helps mitigate moral hazard (Degryse \& de Jong, 2006). Moreover, borrowing from banks can signal to outside investors a firm's good financial standing (Koo \& Maeng, 2008; Ozkan \& Ozkan, 2004). This implies that bank-dependent firms are seen as creditworthy borrowers, which facilitates capital market financing. Finally, bank loans are a substitute for cash. Taking these arguments together, if a firm borrows from banks, it should hold less cash. We predict that firms with more bank debt hold less cash.

We also expect exporters to be more exposed to currency risk. Thus, we add to the model (1) the turnover ratio (EXTurn): the ratio of export sales to net assets.

The regression also includes a proxy for monetary policy $(M P)$ to control for monetary liquidity conditions and the effect of monetary policy changes. We use a measure of the policy type that accounts for the relationship between money demand and money supply (Dai \& Yang, 2015). The variable MP is defined as the M3 growth rate divided by the nominal GDP growth rate. ${ }^{4} \mathrm{~A}$ loose monetary policy should result in excess monetary liquidity (money supply is greater than demand), whereas tight monetary policy leads to a shortage in monetary liquidity.

\section{DATA}

To examine the link between firm-bank relationships and cash holdings, we use data from two sources. We use the SMIDA database from the National Securities and Stock Market Commission for balance sheet and income statement data for Ukrainian companies and the National Bank of Ukraine (NBU) for data on export activities of the firms serviced by banks. Our sample 
includes only non-financial firms with positive sales and we discard the top and bottom $1 \%$ values for all firm-level continuous variables on an annual distribution to mitigate the potential influence of outliers on the parameter estimates in our analysis. After that, the year-end Consumer Price Index (CPI) for Ukraine is used to deflate the variables to 2008 hryvnia (UAH). After applying the filters, we obtain a sample of about 15,500 annual firm observations (for more than 4,000 firms) for the period of 2008-2015. The companies in our sample represent approximately $70 \%$ of large corporate exporters and more than $15 \%$ of all large active corporations in Ukraine.

Table 1 shows the descriptive statistics for the variables used in this study. In our sample, the cash holdings of firms range from almost $0 \%$ to $72.3 \%$ of net assets. Large exporters hold on average about $5 \%$ of net assets as cash reserves, while nonexporters (firms not included in our sample) hold only $4.1 \%$ of net assets as cash. The sample mean of cash flow, defined as the ratio of pre-tax profit plus depreciation and amortization to net assets, is about $9.8 \%$. On average, bank loans represent $12.3 \%$ of total debt; short-term bank financing accounts for $8.6 \%$ of total debt.

About $45 \%$ of firms in the sample work with two or more banks. These firms have a shorter duration of relationship (two years) with their main banks than do firms that work with a single bank (almost three years). This is a preliminary sign that competition among banks/creditors may mitigate the hold-up problem that stems from a main bank's information monopoly.

Firms with multiple bank relationships are larger on average (UAH 21.882 billion in net assets vs. UAH 11.141 million for companies with a single bank), have a greater proportion of long-term debt, and borrow more from banks (13.6\% vs. 10.3\% of total debt), but they also have more short-term loans ( $6.4 \%$ vs. $5.0 \%$ of total debt). The latter underlines the importance of bank monitoring, as it suggests that the presence of more banks may be associated with short-term bank financing and accompanying stronger control from the creditors.

Theory suggests a strong relationship between a firm and a bank can ease financial constraints and smooth out cash flow volatility. To examine how a bank's ability to ease a client's financial constraints affects corporate cash holdings, we first split our full sample into sub-samples of bank-dependent and bank-independent firms. Firms with a low liquidity ratio and those who borrow from banks are treated as bank-dependent firms. We take an annual sample mean of the net working capital ratio to separate firms with different levels of liquidity. Bank-dependent firms face considerable internal constraints (lower cash flow relative to peers). They are highly leveraged and borrow more short-term funds, which entails stricter screening and monitoring from their banks (see Tables 2 and 3).

The descriptive statistics for firms with different levels of sales and cash flow volatility are reported in Tables 4 and 5, respectively. Volatility in sales (cash flow) is defined as the standard deviation of sales (cash flow) divided by the mean of the variable. Firms with more volatile sales and cash flow use more debt financing than do peers. At the same time, firms with high volatility of sales use more short-term bank loans, while firms with high volatility of cash flow use more short-term informal financing like trade credit. The data also show that firms with less bank debt hold more cash.

We will also examine whether firm-bank relationships can attenuate the overinvestment incentives that originate from the managerial discretion problem. We use the cash ratio and a proxy for investment opportunities to identify firms exposed to material agency conflicts between managers and shareholders. Firms with a cash ratio higher than the mean are likely to experience managerial moral hazard as managers accumulate cash to increase their power (Yafeh \& Yosha, 2003). In addition, firms with poor prospects and below-mean sales growth may experience overinvestment issues as managers are incentivized to overspend (Degryse \& de Jong, 2006). Tables 6 and 7 show the descriptive statistics for firms prone to agency conflicts and their peers.

\section{RESULTS}

This section reports our key findings. We begin our analysis by estimating the impact of the length of and number of bank relationships on corporate cash holdings. Our study also tests these links on the sub-samples to estimate the capacity of each channel to alleviate financial constraints and agency conflicts of bank clients.

Table 8 documents the estimation outcomes of the model (1) for the full sample. Here and further we present the results of the regressions with fixed effects (within-group transformations) robust to heteroscedasticity, since the null hypothesis of the Hausman Test (appropriateness of the random effects estimator) is rejected at the $1 \%$ level of significance in all specifications and the model with fixed effects is concluded to be preferable. ${ }^{5}$ In all specifications we also control for industry effects and the business cycle.

The coefficients for all fundamental variables have predicted signs and almost all of them (except debt maturity) are highly significant (at the $1 \%$ level). ${ }^{6}$ Adding key variables that measure different aspects of firm-bank relationships to the base model

\footnotetext{
${ }^{5}$ The Hausman statistics $\left(\chi^{2}\right)$ are reported in tables 8-11.

${ }^{6}$ The lower significance level for debt maturity can be explained to a certain extent by a level of collinearity between the debt maturity and the share of bank loans in total debt. The Pearson correlation coefficient for these two variables is 0.12 , which is not critical and does not distort our main findings.
} 
increases the model's explanatory power. Both $\mathrm{F}$ and t-tests support the relevance of a bank's influence on corporate cash holdings. Notably, the signs and significance levels of the control variables remain unchanged after the inclusion of key variables into the model.

Our findings confirm our key hypotheses about the impact of banks on corporate cash holdings. We also corroborate the findings of Ozkan \& Ozkan (2004): bank financing serves as a substitute for cash reserves.

The results in Table 8 provide strong supporting evidence of the U-shaped relationship between the length of a bank relationship and corporate cash holdings as the estimated coefficients on Duration and Duration ${ }^{2}$ have the expected signs and are significant at the $1 \%$ level in all specifications where they appear (Hypothesis 1). This suggests that firms initially benefit from starting to work with a bank as it allows them to reduce additional cash needs. However, once the relationship matures (after 3 years on average), firms start to increase cash reserves. That tendency is consistent with the notion that lasting relationships give rise to the hold-up problem when a bank acquires private client information not available to other financial institutions and thus gain a measure of control over the client (Fama, 1985; Rajan, 1992).

Our results also confirm the nonlinear relationship (inverted U-shaped) of the number of banks and corporate cash holdings at least at the $5 \%$ level (Hypothesis 2). Engagement of a new bank appears justified if a firm engages a niche bank and increases its cash to cover transaction costs. Otherwise, the positive association between corporate cash and numerous banking relationships indicates free-rider monitoring problem. On average, only competition among five or more banks can reduce financial constraints and corporate cash holdings. The latter evidence is in line with Yu, Sopranzetti \& Lee (2015) and Carletti, Cerasi \& Daltung (2007).

We next analyze the results for the sub-samples. Firms are first separated by their dependence on their main bank (see Table 9). The cash holdings of both bank-dependent groups are not sensitive to bank financing. A plausible explanation for this outcome is that these firms are highly leveraged (see Tables 2 and 3) and may be viewed by lenders as borrowers with low creditworthiness. Thus, firms with a low liquidity ratio and high bank debt can be considered financially constrained. Unlike constrained firms, their high-liquidity peers can substitute cash with bank loans relatively easily. The duration of firm-bank relationships is important for firms with varying levels of net working capital to form liquidity reserves, but the influence of the bank is more pronounced for the unconstrained firms.

The number of bank relationships significantly affects the cash holdings of financially constrained firms. This is the case when a firm with financial constraints applies to a new bank to finance high-risk projects. In this situation, the presence of multiple bank relationships is a sign of a firm's questionable creditworthiness (as shown by Degryse \& Ongena, 2001). The negative and significant coefficients for the non-linear terms mean that an increase in the number of banks results in relaxed financial constraints.

Table 10 provides regression results for the sub-samples of firms with different levels of sales and cash flow volatility. Regardless of volatility, the length of a firm-bank relationship is a significant determinant of cash holdings for all types of firms. Bank debt has a significant and negative effect on cash holdings, but only for firms with a low volatility ratio. Our results show that, unlike their peers, riskier firms tend to work with multiple banks, which helps them curtail sales and cash flow volatility.

Finally, firms effectively use banking relations to resolve agency conflicts between owners and managers (Table 11). At the same time, neither the duration nor number of relationships affect the cash ratio in firms without any agency conflicts. Our key hypotheses about the impact of firm-bank relationships on corporate cash holdings are confirmed in firms with severe agency costs. Similar to the findings of Degryse \& de Jong (2006), bank debt is found to be an efficient tool to address managers' overinvestment incentives. At the outset of a relationship, banks are ready to lend and monitor, which decreases cash levels and attenuates the agency issue. Competition among lenders have a similar effect. Nevertheless, a long-term relationship enables the hold-up problem, while multiple bank relationships may result in the free-rider problem. The latter effects can weaken the benefits from banking relationships for firms with agency conflicts. This means that matured relationships with a main bank and the moral hazard in banking reduce a bank's capacity to resolve agency conflicts.

\section{CONCLUSIONS}

In this paper, we examined the impact of firm-bank relationships on corporate cash holdings using a sample of more than 4,000 Ukrainian companies from 2008 to 2015. We test a bank's capacity to weaken financial constraints and managerial discretion problems by focusing on the effects of the duration and number of bank relationships.

Our findings show that banks play a significant role in monitoring firms by restricting the use of cash that could otherwise be misused by managers. Notably, firms use a bank's influence (duration and number of bank relationships) to resolve agency conflicts and eliminate overinvestment incentives at underperforming firms.

This paper also provides convincing evidence of the non-linear relationship (U-shaped) between the length of a banking relationship and corporate cash holdings. At the onset of a banking relationship, firms benefit from a reduction in the need 
for additional liquidity. However, once the relationship matures (after 3 years on average), firms increase cash because of the hold-up problem that stems from a bank's control over a firm's private information.

We also find a non-linear relationship (inverted U-shaped) between the number of banks and corporate cash holdings. Multiple bank relationships are relevant for financially constrained firms with a significant debt ratio and low creditworthiness. Although the negative and significant coefficients for the non-linear terms show that the competition among banks that service a firm reduces the firm's financial constraints, the positive relationship between corporate cash reserves and the number of banks at low levels of competition may be a signal of a firm's poor creditworthiness (Degryse \& Ongena, 2001) or a risk of the free-rider problem among the banks (Rajan, 1992).

That situation is concerning in the case of a bank that does not sufficiently screen potential borrowers. This institutional problem caused by information asymmetry can be partially addressed through the introduction of a credit registry. A lender may also choose to deliberately take on that risk, which could spur a propagation of risk through firm-bank links (Chan, Lin, Chang \& Liao, 2013). However, any deeper analysis of those related issues is a topic for future research.

\section{References}

- Almeida H., Campello M., Weisbach M.S. (2004). The cash flow sensitivity of cash. Journal of Finance Vol. 59, No. 4, pp. 1777-1805.

- Al-Najjar B. (2013). The financial determinants of corporate cash holdings: Evidence from some emerging markets. International Business Review, Vol. 22, No. 1, pp. 77-88.

- Berger A., Udell G. (1995). Relationship lending and lines of credit in small firm finance. Journal of Business, Vol. 65, pp. 351-381.

- Bigelli M., Sanchez-Vidal J. (2012). Cash holdings in private firms. Journal of Banking and Finance, Vol. 36, No. 1, pp. 26-35.

- Bris A., Welch I. (2005). The optimal concentration of creditors. Journal of Finance, Vol. 60, No. 5, pp. 2193-2212.

- Carletti E., Cerasi V., Daltung S. (2007). Multiple-bank lending: Diversification and free-riding in monitoring. Journal of Financial Intermediation, Vol. 16, No. 3, pp. 425-451.

- Chan C.-C., Lin B.-H., Chang Y.-H., Liao W.-C. (2013). Does bank relationship matter for corporate risk-taking? Evidence from listed firms in Taiwan. North American Journal of Economics and Finance, Vol. 26, pp. 323-338.

- Dai B., Yang F. (2015). Monetary policy, accounting conservatism and trade credit, China Journal of Accounting Research, Vol. 8, No. 4, pp. 295-313.

- Degryse H., de Jong A. (2006). Investment and internal finance: Asymmetric information and managerial discretion? International Journal of Industrial Organization, Vol. 24, No. 1, pp. 125-147.

- Degryse H., Ongena S. (2001). Bank relationships and firm profitability. Financial Management, Vol. 30, No.1, pp. 9-34.

- Dell'Ariccia G., Marquez R. (2004). Information and bank credit allocation, Journal of Financial Economics, Vol. 72, No. 1, pp. $185-214$.

- Detragiache E., Garella, P., Guiso L. (2000). Multiple versus single banking relationships: Theory and evidence. Journal of Finance, Vol. 55, No. 3, pp. 1133-1161.

- Diamond D. W. (1991). Monitoring and reputation: The choice between bank loans and directly placed debt. Journal of Political Economy, Vol. 99, No. 4, pp. 689-721.

- Dittmar A., Mahrt-Smith J., Servaes H. (2003). International corporate governance and corporate cash holdings. Journal of Financial and Quantitative Analysis, Vol. 38, No. 1, pp. 111-133.

- Fama E.F. (1985). What's different about banks? Journal of Monetary Economics, Vol. 15, No. 1, pp. 29-39.

- Ferreira M.A., Vilela A.S. (2003). Why do firms hold cash? Evidence from EMU countries, Discussion paper, ISCTE.

- Gopalan R., Udell G.F., Yerramilli V. (2011). Why do firms form new banking relationships? Journal of Financial and Quantitative Analysis, Vol. 46, No. 5, pp. 1335-1365.

- Han S., Qiu J. (2007). Corporate precautionary cash holdings. Journal of Corporate Finance, Vol. 13, pp. 43-57.

- Harford J., Klasa S., Maxwell W.F. (2014). Refinancing risk and cash holdings. Journal of Finance, Vol. 69, No. 3, pp. $975-1012$.

- Holmstrom B. (1982). Moral hazard in teams. Bell Journal of Economics, Vol. 13, No. 2, pp. 324-340.

- Ioannidou V., Ongena S. (2006). Time for change: Loan conditions and bank behavior when firms switch. Working paper, Tilburg University and CEPR. 
- Jensen M. (1986). Agency costs of free cash flow, corporate finance and takeovers. American Economic Review, Vol. 76, pp. 323-329.

- Keynes, J. M. (1936). The General Theory of Employment, Interest and Money. Harcourt, Brace and Company. New York.

- Kim C.-S., Mauer D.C., Sherman A.E. (1998). The determinants of corporate liquidity: Theory and evidence, Journal of Financial and Quantitative Analysis, Vol. 33, No. 3, pp. 335-359.

- Kim M., Kliger D., Vale B. (2003). Estimating switching costs: The case of banking. Journal of Financial Intermediation, Vol. 12, pp. 25-56.

- Klemperer P. (1995). Competition when consumers have switching costs: An overview with applications to industrial organization, macroeconomics, and international trade. Review of Economic Studies, Vol. 62, pp. 515-539.

- Koo J., Maeng K. (2008). Bank-dependence, financial constraints and investment: Evidence from Korea. Journal of the Korean Economy, Vol. 9, No. 1, pp. 89-112.

- Luo Q., Hachiya T. (2005). Corporate governance, cash holdings, and firm value: Evidence from Japan. Review of Pacific Basin Financial Markets and Policies, Vol. 8, No. 4, pp. 613-636.

- Miller M.H., Orr D. (1966). A Model of the Demand for Money by Firms. Quarterly Journal of Economics, Vol. 80, No. 3, pp. 413-435.

- Myers S., Majluf N. (1984). Corporate financing and investment decision when firms have information that investors do not have. Journal of Financial Economics, Vol. 13, pp. 187-221.

- National Bank of Ukraine of Ukraine (2016). Financial stability report, Technical report, National Bank of Ukraine.

- Opler T., Pinkowitz L., Williamson R. (1999). The determinants and implications of corporate cash holdings. Journal of Financial Economics, Vol. 52, pp. 3-46.

- Ozkan A., Ozkan N. (2004). Corporate cash holdings: An empirical investigation of UK companies. Journal of Banking and Finance, Vol. 28, No. 9, pp. 2103-2134.

- Petersen M., Rajan R. (1994). The benefits of lending relationships: Evidence from small business data, Journal of Finance, Vol. 49, pp. 3-37.

- Pinkowitz L., Williamson R. (2001). Bank power and cash holdings: Evidence from Japan. Review of Financial Studies, Vol. 4, pp. 1059-1082.

- Rajan R. (1992). Insiders and Outsiders: The Choice between Informed and Arm's-Length Debt'. Journal of Finance, Vol. 47, No. 4, pp. 1367-1400.

- Sharpe S. (1990). Asymmetric Information, Bank Lending, and Implicit Contracts: A Stylized Model of Customer Relationships. Journal of Finance, Vol. 45, No. 4, pp. 1069-1087.

- Shen C.-H., Huang, A.-H. (2003). Are performances of banks and firms linked? And if so, why? Journal of Policy Modeling, Vol. 25, No. 4, pp. 397-414.

- Singh A. (2003). Competition, corporate governance and selection in emerging markets. The Economic Journal, Vol. 113, pp. 443-464.

- Stephan A., Tsapin A., Talavera O. (2012). Main Bank Ppower, Switching Costs, and Firm Performance: Theory and Evidence from Ukraine. Emerging Markets Finance and Trade, Vol. 48, No. 2, pp. 76-93.

- Sufi A. (2007). Information asymmetry and financing arrangements: Evidence from syndicated loans, Journal of Finance, Vol. 62, No. 2, pp. 629-668.

- Uyar A., Kuzey C. (2014). Determinants of corporate cash holdings: Evidence from the emerging market of Turkey. Applied Economics, Vol. 46, No. 9, pp. 1035-1048.

- von Thadden, E.-L. (2004). Asymmetric information, bank lending and implicit contracts: The winner's curse. Finance Research Letters? Vol. 1, No. 1, pp. 11-23.

- Wu W., Rui O.M., Wu C. (2012). Trade credit, cash holdings, and financial deepening: Evidence from a transitional economy. Journal of Banking and Finance, Vol. 36, No. 11, pp. 2868-2883.

- Yafeh Y., Yosha O. (2003). Large Shareholders and Banks: Who monitors and How? Economic Journal, Vol. 113, No. 484, pp. 128-146.

- Yu H.-C., Sopranzetti B.J., Lee C.-F. (2015). The impact of banking relationships, managerial incentives, and board monitoring on corporate cash holdings: An emerging market perspective. Review of Quantitative Finance and Accounting, Vol. 44, No. 2, pp. 353-378. 


\section{APPENDIX}

Table 1. Descriptive Statistics: All Firms

\begin{tabular}{|l|c|c|c|c|}
\hline Variable & $\mu$ & $\sigma$ & Min & Max \\
\hline Cash & 0.050 & 0.088 & 0.000 & 0.723 \\
\hline NWC & 0.102 & 0.334 & -2.249 & 0.889 \\
\hline Size & 11.841 & 1.592 & 7.143 & 16.219 \\
\hline Growth & 1.031 & 0.387 & 0.063 & 3.319 \\
\hline EXTurn & 0.034 & 0.061 & 0.000 & 2.295 \\
\hline CF & 0.098 & 0.217 & -1.332 & 1.809 \\
\hline Leverage & 0.596 & 0.387 & 0.017 & 2.858 \\
\hline DM & 0.178 & 0.255 & 0.000 & 0.946 \\
\hline BC & 0.123 & 0.192 & 0.000 & 0.997 \\
\hline STBC & 0.086 & 0.169 & 0.000 & 0.834 \\
\hline Duration & 2.505 & 1.713 & 1 & 8 \\
\hline NB & 1.415 & 0.741 & 1 & 11 \\
\hline MP & 1.151 & 0.052 & 1.087 & 1.273 \\
\hline N & & & 15,482 & \\
\hline
\end{tabular}

Note: Cash is the ratio of cash to net assets, where net assets are defined as total assets excluding cash. Net assets are defined as total assets minus cash. NWC is constructed as the ratio of net working capital minus cash to net assets. Size is the natural logarithm of net assets. Growth is defined as the growth of a company's sales. CF is constructed as cash flow divided by net assets. EXTurn is the ratio of export sales to net assets. Leverage is total debt over net assets. $D M$ is the share of long-term debt in a company's total debt. $B C$ is the share of bank loans in a company's total debt. STBC is the share of short-term bank debt in a company's total debt. Duration is the length of a firm's relationship with its main bank in years. NB is the number of banks with which a firm works. 
Table 2. Descriptive Statistics for Firms with Low and High Liquidity

\begin{tabular}{|l|c|c|c|c|}
\hline \multirow{2}{*}{ Variable } & \multicolumn{2}{|c|}{ Low Liquidity } & \multicolumn{2}{c}{ High Liquidity } \\
\cline { 2 - 5 } & $\mu$ & $\sigma$ & $\mu$ & $\sigma$ \\
\hline Cash & 0.042 & 0.083 & 0.058 & 0.092 \\
\hline NWC & -0.167 & 0.252 & 0.338 & 0.180 \\
\hline Size & 11.849 & 1.672 & 11.826 & 1.521 \\
\hline Growth & 1.032 & 0.398 & 1.030 & 0.377 \\
\hline EXTurn & 0.035 & 0.072 & 0.032 & 0.049 \\
\hline CF & 0.075 & 0.234 & 0.119 & 0.197 \\
\hline Leverage & 0.756 & 0.395 & 0.456 & 0.320 \\
\hline DM & 0.137 & 0.214 & 0.216 & 0.282 \\
\hline BC & 0.119 & 0.184 & 0.112 & 0.170 \\
\hline STBC & 0.097 & 0.178 & 0.076 & 0.159 \\
\hline Duration & 2.455 & 1.698 & 2.548 & 1.726 \\
\hline NB & 1.402 & 0.744 & 1.428 & 0.740 \\
\hline N & & 7,093 & & 8,236 \\
\hline
\end{tabular}

Note: Cash is the ratio of cash to net assets, where net assets are defined as total assets excluding cash. Net assets are defined as total assets minus cash. NWC is constructed as the ratio of net working capital minus cash to net assets. Size is the natural logarithm of net assets. Growth is defined as the growth of a company's sales. CF is constructed as cash flow divided by net assets. EXTurn is the ratio of export sales to net assets. Leverage is total debt over net assets. DM is the share of long-term debt in a company's total debt. BC is the share of bank loans in a company's total debt. STBC is the share of short-term bank debt in a company's total debt. Duration is the length of a firm's relationship with its main bank in years. NB is the number of banks with which a firm works.

Table 3. Descriptive Statistics for Firms with and without Bank Debt

\begin{tabular}{|l|c|c|c|c|}
\hline \multirow{2}{*}{ Variable } & \multicolumn{2}{|c|}{ Bank Loans $>0$} & \multicolumn{2}{c}{ Bank Loans $=0$} \\
\cline { 2 - 5 } & $\mu$ & $\sigma$ & $\mu$ & $\sigma$ \\
\hline Cash & 0.028 & 0.054 & 0.073 & 0.108 \\
\hline NWC & 0.083 & 0.317 & 0.125 & 0.346 \\
\hline Size & 12.292 & 1.529 & 11.372 & 1.521 \\
\hline Growth & 1.026 & 0.382 & 1.036 & 0.392 \\
\hline EXTurn & 0.027 & 0.057 & 0.040 & 0.064 \\
\hline CF & 0.065 & 0.194 & 0.133 & 0.232 \\
\hline Leverage & 0.683 & 0.362 & 0.506 & 0.390 \\
\hline DM & 0.248 & 0.273 & 0.110 & 0.216 \\
\hline BC & 0.228 & 0.190 & 0.000 & 0.000 \\
\hline STBC & 0.170 & 0.205 & 0.000 & 0.000 \\
\hline Duration & 2.354 & 1.619 & 2.659 & 1.792 \\
\hline NB & 1.511 & 0.847 & 1.319 & 0.600 \\
\hline N & & 7,738 & & 7,591 \\
\hline
\end{tabular}

Note: Cash is the ratio of cash to net assets, where net assets are defined as total assets excluding cash. Net assets are defined as total assets minus cash. NWC is constructed as the ratio of net working capital minus cash to net assets. Size is the natural logarithm of net assets. Growth is defined as the growth of a company's sales. CF is constructed as cash flow divided by net assets. EXTurn is the ratio of export sales to net assets. Leverage is total debt over net assets. $D M$ is the share of long-term debt in a company's total debt. $B C$ is the share of bank loans in a company's total debt. STBC is the share of short-term bank debt in a company's total debt. Duration is the length of a firm's relationship with its main bank in years. NB is the number of banks with which a firm works. 
Table 4. Descriptive Statistics for Firms with Low and High Volatility of Sales

\begin{tabular}{|l|c|c|c|c|}
\hline \multirow{2}{*}{ Variable } & \multicolumn{2}{|c||}{ Low Volatility of Sales } & \multicolumn{2}{c|}{ High Volatility of Sales } \\
\cline { 2 - 5 } & $\mu$ & $\sigma$ & $\mu$ & $\sigma$ \\
\hline Cash & 0.054 & 0.090 & 0.045 & 0.084 \\
\hline NWC & 0.113 & 0.324 & 0.082 & 0.350 \\
\hline Size & 11.722 & 1.601 & 12.050 & 1.553 \\
\hline Growth & 1.018 & 0.303 & 1.054 & 0.502 \\
\hline EXTurn & 0.036 & 0.061 & 0.029 & 0.060 \\
\hline CF & 0.115 & 0.214 & 0.068 & 0.217 \\
\hline Leverage & 0.559 & 0.372 & 0.661 & 0.404 \\
\hline DM & 0.172 & 0.250 & 0.189 & 0.263 \\
\hline BC & 0.121 & 0.191 & 0.127 & 0.192 \\
\hline STBC & 0.084 & 0.168 & 0.088 & 0.170 \\
\hline Duration & 2.571 & 1.746 & 2.388 & 1.646 \\
\hline NB & 1.441 & 0.745 & 1.371 & 0.734 \\
\hline N & & 9,871 & & \\
\hline
\end{tabular}

Note: Cash is the ratio of cash to net assets, where net assets are defined as total assets excluding cash. Net assets are defined as total assets minus cash. NWC is constructed as the ratio of net working capital minus cash to net assets. Size is the natural logarithm of net assets. Growth is defined as the growth of a company's sales. CF is constructed as cash flow divided by net assets. EXTurn is the ratio of export sales to net assets. Leverage is total debt over net assets. $D M$ is the share of long-term debt in a company's total debt. $B C$ is the share of bank loans in a company's total debt. STBC is the share of short-term bank debt in a company's total debt. Duration is the length of a firm's relationship with its main bank in years. NB is the number of banks with which a firm works.

Table 5. Descriptive Statistics for Firms with Low and High Volatility of Cash Flow

\begin{tabular}{|l|c|c|c|c|}
\hline \multirow{2}{*}{ Variable } & \multicolumn{2}{c|}{ Low Volatility of Cash Flow } & \multicolumn{2}{c|}{ High Volatility of Cash Flow } \\
\cline { 2 - 5 } & $\mu$ & $\sigma$ & $\mu$ & $\sigma$ \\
\hline Cash & 0.047 & 0.082 & 0.055 & 0.096 \\
\hline NWC & 0.100 & 0.336 & 0.106 & 0.332 \\
\hline Size & 11.850 & 1.582 & 11.825 & 1.607 \\
\hline Growth & 1.021 & 0.374 & 1.047 & 0.407 \\
\hline EXTurn & 0.034 & 0.064 & 0.033 & 0.056 \\
\hline CF & 0.093 & 0.214 & 0.106 & 0.220 \\
\hline Leverage & 0.588 & 0.400 & 0.610 & 0.365 \\
\hline DM & 0.180 & 0.257 & 0.175 & 0.253 \\
\hline BC & 0.127 & 0.194 & 0.115 & 0.187 \\
\hline STBC & 0.089 & 0.171 & 0.080 & 0.164 \\
\hline Duration & 2.412 & 1.648 & 2.656 & 1.804 \\
\hline NB & 1.414 & 0.743 & 1.418 & 0.740 \\
\hline N & & 9,593 & & \\
\hline
\end{tabular}

Note: Cash is the ratio of cash to net assets, where net assets are defined as total assets excluding cash. Net assets are defined as total assets minus cash. NWC is constructed as the ratio of net working capital minus cash to net assets. Size is the natural logarithm of net assets. Growth is defined as the growth of a company's sales. CF is constructed as cash flow divided by net assets. EXTurn is the ratio of export sales to net assets. Leverage is total debt over net assets. $D M$ is the share of long-term debt in a company's total debt. $B C$ is the share of bank loans in a company's total debt. STBC is the share of short-term bank debt in a company's total debt. Duration is the length of a firm's relationship with its main bank in years. NB is the number of banks with which a firm works. 
Table 6. Descriptive Statistics for Firms with Low and High Cash Ratios

\begin{tabular}{|l|c|c|c|c|}
\hline \multirow{2}{*}{ Variable } & \multicolumn{2}{|c|}{ Low Cash Ratio } & \multicolumn{2}{c|}{ High Cash Ratio } \\
\cline { 2 - 5 } & $\mu$ & $\sigma$ & $\mu$ & $\sigma$ \\
\hline Cash & 0.004 & 0.004 & 0.093 & 0.105 \\
\hline NWC & 0.052 & 0.331 & 0.149 & 0.330 \\
\hline Size & 12.000 & 1.600 & 11.693 & 1.570 \\
\hline Growth & 1.004 & 0.401 & 1.056 & 0.373 \\
\hline EXTurn & 0.024 & 0.048 & 0.043 & 0.070 \\
\hline CF & 0.063 & 0.201 & 0.130 & 0.225 \\
\hline Leverage & 0.636 & 0.379 & 0.558 & 0.391 \\
\hline DM & 0.197 & 0.262 & 0.160 & 0.247 \\
\hline BC & 0.147 & 0.198 & 0.100 & 0.183 \\
\hline STBC & 0.102 & 0.178 & 0.070 & 0.158 \\
\hline Duration & 2.399 & 1.635 & 2.603 & 1.778 \\
\hline NB & 1.388 & 0.715 & 1.441 & 0.765 \\
\hline N & & 7,465 & & 8,015 \\
\hline
\end{tabular}

Note: Cash is the ratio of cash to net assets, where net assets are defined as total assets excluding cash. Net assets are defined as total assets minus cash. NWC is constructed as the ratio of net working capital minus cash to net assets. Size is the natural logarithm of net assets. Growth is defined as the growth of a company's sales. CF is constructed as cash flow divided by net assets. EXTurn is the ratio of export sales to net assets. Leverage is total debt over net assets. $D M$ is the share of long-term debt in a company's total debt. $B C$ is the share of bank loans in a company's total debt. STBC is the share of short-term bank debt in a company's total debt. Duration is the length of a firm's relationship with its main bank in years. NB is the number of banks with which a firm works.

Table 7. Descriptive Statistics for Firms with Low and High Growth

\begin{tabular}{|l|c|c||c|c|}
\hline \multirow{2}{*}{ Variable } & \multicolumn{3}{|c||}{ Low Growth } & \multicolumn{2}{c}{ High Growth } \\
\cline { 2 - 5 } & $\mu$ & $\sigma$ & $\mu$ & $\sigma$ \\
\hline Cash & 0.045 & 0.084 & 0.057 & 0.093 \\
\hline NWC & 0.103 & 0.336 & 0.101 & 0.331 \\
\hline Size & 11.818 & 1.597 & 11.872 & 1.584 \\
\hline Growth & 0.808 & 0.223 & 1.331 & 0.359 \\
\hline EXTurn & 0.029 & 0.054 & 0.040 & 0.068 \\
\hline CF & 0.080 & 0.219 & 0.122 & 0.211 \\
\hline Leverage & 0.589 & 0.393 & 0.606 & 0.379 \\
\hline DM & 0.182 & 0.258 & 0.172 & 0.251 \\
\hline BC & 0.127 & 0.194 & 0.117 & 0.188 \\
\hline STBC & 0.088 & 0.171 & 0.083 & 0.165 \\
\hline Duration & 2.503 & 1.693 & 2.508 & 1.740 \\
\hline NB & 1.408 & 0.733 & 1.426 & 0.753 \\
\hline N & & 8,887 & & 6,595 \\
\hline
\end{tabular}

Note: Cash is the ratio of cash to net assets, where net assets are defined as total assets excluding cash. Net assets are defined as total assets minus cash. NWC is constructed as the ratio of net working capital minus cash to net assets. Size is the natural logarithm of net assets. Growth is defined as the growth of a company's sales. CF is constructed as cash flow divided by net assets. EXTurn is the ratio of export sales to net assets. Leverage is total debt over net assets. $D M$ is the share of long-term debt in a company's total debt. $B C$ is the share of bank loans in a company's total debt. STBC is the share of short-term bank debt in a company's total debt. Duration is the length of a firm's relationship with its main bank in years. NB is the number of banks with which a firm works. 
Table 8. Corporate Cash Holdings and Bank Relationships: Results for All Firms

\begin{tabular}{|c|c|c|c|c|c|}
\hline Cash & (1) & (2) & (3) & (4) & (5) \\
\hline NWC & $\begin{array}{c}-0.0202^{* * *} \\
(0.0065)\end{array}$ & $\begin{array}{c}-0.0206^{* * *} \\
(0.0065)\end{array}$ & $\begin{array}{c}-0.0198^{* * *} \\
(0.0064)\end{array}$ & $\begin{array}{c}-0.0201^{* * *} \\
(0.0064)\end{array}$ & $\begin{array}{c}-0.0201^{* * *} \\
(0.0064)\end{array}$ \\
\hline Size & $\begin{array}{c}-0.0229^{* * *} \\
(0.0030)\end{array}$ & $\begin{array}{c}-0.0226^{* * *} \\
(0.0030)\end{array}$ & $\begin{array}{l}-0.022^{* * *} \\
(0.0030)\end{array}$ & $\begin{array}{c}-0.0230^{* * *} \\
(0.0030)\end{array}$ & $\begin{array}{c}-0.0230^{* * *} \\
(0.0030)\end{array}$ \\
\hline Growth & $\begin{array}{l}0.0106^{* * *} \\
(0.0018)\end{array}$ & $\begin{array}{l}0.0105^{* * *} \\
(0.0018)\end{array}$ & $\begin{array}{l}0.0101^{* * *} \\
(0.0018)\end{array}$ & $\begin{array}{l}0.0100^{* * *} \\
(0.0018)\end{array}$ & $\begin{array}{l}0.0100^{* * *} \\
(0.0018)\end{array}$ \\
\hline EXTurn & $\begin{array}{l}0.1830^{* * *} \\
(0.0407)\end{array}$ & $\begin{array}{l}0.1828^{* * *} \\
(0.0408)\end{array}$ & $\begin{array}{l}0.1859^{* * *} \\
(0.0409)\end{array}$ & $\begin{array}{l}0.1862^{* * *} \\
(0.0408)\end{array}$ & $\begin{array}{c}0.1862^{* * *} \\
(0.0408)\end{array}$ \\
\hline CF & $\begin{array}{l}0.0439^{* * *} \\
(0.0046)\end{array}$ & $\begin{array}{l}0.0437^{* * *} \\
(0.0046)\end{array}$ & $\begin{array}{l}0.0433^{* * *} \\
(0.0045)\end{array}$ & $\begin{array}{l}0.0431^{* * *} \\
(0.0045)\end{array}$ & $\begin{array}{l}0.0431^{* * *} \\
(0.0045)\end{array}$ \\
\hline Leverage & $\begin{array}{l}0.0303^{* * *} \\
(0.0064)\end{array}$ & $\begin{array}{l}0.0305^{* * *} \\
(0.0064)\end{array}$ & $\begin{array}{l}0.0313^{* * *} \\
(0.0064)\end{array}$ & $\begin{array}{l}0.0314^{* * *} \\
(0.0064)\end{array}$ & $\begin{array}{l}0.0314^{* * *} \\
(0.0064)\end{array}$ \\
\hline DM & $\begin{array}{l}0.0123^{* *} \\
(0.0060)\end{array}$ & $\begin{array}{l}0.0119^{* *} \\
(0.0060)\end{array}$ & $\begin{array}{c}0.0115^{*} \\
(0.0060)\end{array}$ & $\begin{array}{l}0.0122^{* *} \\
(0.0060)\end{array}$ & $\begin{array}{l}0.0122^{* *} \\
(0.0060)\end{array}$ \\
\hline$B C$ & & $\begin{array}{c}-0.0137^{* *} \\
(0.0066)\end{array}$ & $\begin{array}{c}-0.0137^{* *} \\
(0.0065)\end{array}$ & $\begin{array}{c}-0.0140^{* *} \\
(0.0065)\end{array}$ & $\begin{array}{c}-0.0140^{* *} \\
(0.0065)\end{array}$ \\
\hline Duration & & & $\begin{array}{c}-0.0078^{* * *} \\
(0.0018)\end{array}$ & $\begin{array}{c}-0.0068^{* * *} \\
(0.0018)\end{array}$ & $\begin{array}{c}-0.0068^{* * *} \\
(0.0018)\end{array}$ \\
\hline Duration ${ }^{2}$ & & & $\begin{array}{l}0.0012^{* * *} \\
(0.0003)\end{array}$ & $\begin{array}{l}0.0011^{* * *} \\
(0.0003)\end{array}$ & $\begin{array}{l}0.0011^{* * *} \\
(0.0003)\end{array}$ \\
\hline NB & & & & $\begin{array}{l}0.0078^{* * *} \\
(0.0020)\end{array}$ & $\begin{array}{l}0.0078^{* * *} \\
(0.0020)\end{array}$ \\
\hline$N^{2}$ & & & & $\begin{array}{c}-0.0008^{* *} \\
(0.0003)\end{array}$ & $\begin{array}{c}-0.0008^{* *} \\
(0.0003)\end{array}$ \\
\hline MP & & & & & $\begin{array}{l}0.3601^{* * *} \\
(0.0941)\end{array}$ \\
\hline $\mathrm{R}^{2}$ & 0.1131 & 0.1137 & 0.1172 & 0.1188 & 0.1188 \\
\hline $\mathrm{F}$ & 17.445 & 16.909 & 15.928 & 15.294 & 15.294 \\
\hline$\chi^{2}$ & $501.99^{* * *}$ & $507.48^{* * *}$ & $528.14^{* * *}$ & $533.43^{* * *}$ & $533.43^{* * *}$ \\
\hline$N$ & 15,482 & 15,482 & 15,482 & 15,482 & 15,482 \\
\hline
\end{tabular}

Note: $i$ refers to a firm, $t$ refers to time. Each equation includes year and industry dummy variables. Robust standard errors are reported in parentheses. ${ }^{*} p<0.10,{ }^{* *} p<0.05,{ }^{* * *} p<0.01$.

Cash is the ratio of cash to net assets, where net assets are defined as total assets excluding cash. Net assets are defined as total assets minus cash. NWC is constructed as the ratio of net working capital minus cash to net assets. Size is the natural logarithm of net assets. Growth is defined as the growth of a company's sales. CF is constructed as cash flow divided by net assets. EXTurn is the ratio of export sales to net assets. Leverage is total debt over net assets. DM is the share of long-term debt in a company's total debt. BC is the share of bank loans in a company's total debt. STBC is the share of short-term bank debt in a company's total debt. Duration is the length of a firm's relationship with its main bank in years. NB is the number of banks with which a firm works. 
Table 9. Corporate Cash Holdings and Bank Relationships: Do Banks Affect Financial Constraints?

\begin{tabular}{|c|c|c|c|c|}
\hline \multirow{3}{*}{ Cash } & \multicolumn{2}{|c|}{ Bank-Dependent } & \multicolumn{2}{|c|}{ Bank-Independent } \\
\hline & Low Liquidity & Bank Loans > 0 & High Liquidity & Bank Loans $=0$ \\
\hline & (1) & $(2)$ & (3) & (4) \\
\hline NWC & $\begin{array}{c}-0.0283^{* *} \\
(0.0122)\end{array}$ & $\begin{array}{l}-0.0122 \\
(0.0070)\end{array}$ & $\begin{array}{l}-0.0191 \\
(0.0128)\end{array}$ & $\begin{array}{l}-0.0305^{* *} \\
(0.0122)\end{array}$ \\
\hline Size & $\begin{array}{c}-0.0130^{* * *} \\
(0.0045)\end{array}$ & $\begin{array}{c}-0.0164^{* * *} \\
(0.0034)\end{array}$ & $\begin{array}{c}-0.0335^{* * *} \\
(0.0053)\end{array}$ & $\begin{array}{c}-0.0350^{* * *} \\
(0.0051)\end{array}$ \\
\hline Growth & $\begin{array}{l}0.0110^{* * *} \\
(0.0025)\end{array}$ & $\begin{array}{l}0.0084^{* * *} \\
(0.0018)\end{array}$ & $\begin{array}{l}0.0086^{* *} \\
(0.0028)\end{array}$ & $\begin{array}{l}0.0118^{* * *} \\
(0.0035)\end{array}$ \\
\hline EXTurn & $\begin{array}{l}0.1130^{* *} \\
(0.0510)\end{array}$ & $\begin{array}{l}0.0976^{* *} \\
(0.0409)\end{array}$ & $\begin{array}{l}0.2517^{* * *} \\
(0.0475)\end{array}$ & $\begin{array}{l}0.2177^{* * *} \\
(0.0577)\end{array}$ \\
\hline CF & $\begin{array}{l}0.0448^{* * *} \\
(0.0063)\end{array}$ & $\begin{array}{l}0.0235^{* * *} \\
(0.0052)\end{array}$ & $\begin{array}{l}0.0424^{* * *} \\
(0.0070)\end{array}$ & $\begin{array}{l}0.0551^{* * *} \\
(0.0069)\end{array}$ \\
\hline Leverage & $\begin{array}{l}0.0302^{* * *} \\
(0.0091)\end{array}$ & $\begin{array}{l}0.0238^{* * *} \\
(0.0069)\end{array}$ & $\begin{array}{l}0.0266^{* *} \\
(0.0119)\end{array}$ & $\begin{array}{l}0.0496^{* * *} \\
(0.0122)\end{array}$ \\
\hline DM & $\begin{array}{c}0.0121 \\
(0.0112)\end{array}$ & $\begin{array}{c}0.0036 \\
(0.0059)\end{array}$ & $\begin{array}{c}0.0030 \\
(0.0086)\end{array}$ & $\begin{array}{c}0.0205 \\
(0.0124)\end{array}$ \\
\hline BC & $\begin{array}{c}0.0012 \\
(0.0092)\end{array}$ & $\begin{array}{l}-0.0038 \\
(0.0058)\end{array}$ & $\begin{array}{c}-0.0399^{* * *} \\
(0.0090)\end{array}$ & \\
\hline Duration & $\begin{array}{c}-0.0059^{* *} \\
(0.0025)\end{array}$ & $\begin{array}{c}-0.0015 \\
(0.0016)\end{array}$ & $\begin{array}{c}-0.0072^{* *} \\
(0.0025)\end{array}$ & $\begin{array}{c}-0.0077^{* *} \\
(0.0031)\end{array}$ \\
\hline Duration ${ }^{2}$ & $\begin{array}{l}0.0008^{* *} \\
(0.0004)\end{array}$ & $\begin{array}{c}0.0003 \\
(0.0002)\end{array}$ & $\begin{array}{l}0.0013^{* * *} \\
(0.0004)\end{array}$ & $\begin{array}{l}0.0013^{* * *} \\
(0.0004)\end{array}$ \\
\hline NB & $\begin{array}{l}0.0068^{* *} \\
(0.0027)\end{array}$ & $\begin{array}{l}0.0039^{* *} \\
(0.0016)\end{array}$ & $\begin{array}{l}0.0078^{* *} \\
(0.0034)\end{array}$ & $\begin{array}{c}0.0131 \\
(0.0085)\end{array}$ \\
\hline $\mathrm{NB}^{2}$ & $\begin{array}{l}-0.0007^{*} \\
(0.0004)\end{array}$ & $\begin{array}{l}-0.0004^{*} \\
(0.0002)\end{array}$ & $\begin{array}{c}-0.0007 \\
(0.0006)\end{array}$ & $\begin{array}{c}-0.0013 \\
(0.0021)\end{array}$ \\
\hline MP & $\begin{array}{l}0.4871^{* * *} \\
(0.1457)\end{array}$ & $\begin{array}{c}-0.1165 \\
(0.0869)\end{array}$ & $\begin{array}{c}0.2722^{*} \\
(0.1341)\end{array}$ & $\begin{array}{l}0.6588^{* * *} \\
(0.1623)\end{array}$ \\
\hline $\mathrm{R}^{2}$ & 0.134 & 0.075 & 0.118 & 0.162 \\
\hline$\chi^{2}$ & $191.29^{* * *}$ & $178.34^{* * *}$ & $290.72^{* * *}$ & $392.75^{* * *}$ \\
\hline N & 7,093 & 7,738 & 8,236 & 7,591 \\
\hline
\end{tabular}

Note: $i$ refers to a firm, $t$ refers to time. Each equation includes year and industry dummy variables. Robust standard errors are reported in parentheses. ${ }^{*} p<0.10,{ }^{* *} p<0.05,{ }^{* * *} p<0.01$.

Cash is the ratio of cash to net assets, where net assets are defined as total assets excluding cash. Net assets are defined as total assets minus cash. NWC is constructed as the ratio of net working capital minus cash to net assets. Size is the natural logarithm of net assets. Growth is defined as the growth of a company's sales. CF is constructed as cash flow divided by net assets. EXTurn is the ratio of export sales to net assets. Leverage is total debt over net assets. $D M$ is the share of long-term debt in a company's total debt. BC is the share of bank loans in a company's total debt. STBC is the share of short-term bank debt in a company's total debt. Duration is the length of a firm's relationship with its main bank in years. NB is the number of banks with which a firm works. 
Table 10. Corporate Cash Holdings and Bank Relationships: Do Banks Assist Firms in Curbing Volatility?

\begin{tabular}{|c|c|c|c|c|}
\hline \multirow{3}{*}{ Cash } & \multicolumn{2}{|c|}{ Low Volatility } & \multicolumn{2}{|c|}{ High Volatility } \\
\hline & Sales & Cash Flow & Sales & Cash Flow \\
\hline & (1) & (2) & (3) & (4) \\
\hline NWC & $\begin{array}{c}-0.0290^{* * *} \\
(0.0085)\end{array}$ & $\begin{array}{c}-0.0183^{* *} \\
(0.0068)\end{array}$ & $\begin{array}{c}-0.0064 \\
(0.0098)\end{array}$ & $\begin{array}{c}-0.0071 \\
(0.0121)\end{array}$ \\
\hline Size & $\begin{array}{c}-0.0288^{* * *} \\
(0.0041)\end{array}$ & $\begin{array}{c}-0.0241^{* * *} \\
(0.0038)\end{array}$ & $\begin{array}{c}-0.0191^{* * *} \\
(0.0042)\end{array}$ & $\begin{array}{c}-0.0191^{* * *} \\
(0.0046)\end{array}$ \\
\hline Growth & $\begin{array}{l}0.0131^{* * *} \\
(0.0029)\end{array}$ & $\begin{array}{c}0.0089^{* * *} \\
(0.0022)\end{array}$ & $\begin{array}{l}0.0074^{* * *} \\
(0.0023)\end{array}$ & $\begin{array}{l}0.0066^{* * *} \\
(0.0031)\end{array}$ \\
\hline EXTurn & $\begin{array}{l}0.1474^{* * *} \\
(0.0506)\end{array}$ & $\begin{array}{l}0.1605^{* * *} \\
(0.0470)\end{array}$ & $\begin{array}{l}0.2563^{* * *} \\
(0.0494)\end{array}$ & $\begin{array}{c}0.2787^{* * *} \\
(0.0549)\end{array}$ \\
\hline $\mathrm{CF}$ & $\begin{array}{l}0.0530^{* * *} \\
(0.0056)\end{array}$ & $\begin{array}{l}0.0325^{* * *} \\
(0.0049)\end{array}$ & $\begin{array}{l}0.0267^{* * *} \\
(0.0073)\end{array}$ & $\begin{array}{c}0.0299^{* * *} \\
(0.0074)\end{array}$ \\
\hline Leverage & $\begin{array}{l}0.0355^{* * *} \\
(0.0089)\end{array}$ & $\begin{array}{l}0.0295^{* * *} \\
(0.0072)\end{array}$ & $\begin{array}{l}0.0281^{* * *} \\
(0.0087)\end{array}$ & $\begin{array}{c}0.0435^{* * *} \\
(0.0118)\end{array}$ \\
\hline DM & $\begin{array}{l}0.0198^{* * *} \\
(0.0073)\end{array}$ & $\begin{array}{c}0.0104 \\
(0.0072)\end{array}$ & $\begin{array}{c}-0.0005 \\
(0.0100)\end{array}$ & $\begin{array}{c}0.0052 \\
(0.0095)\end{array}$ \\
\hline $\mathrm{BC}$ & $\begin{array}{c}-0.0166^{* *} \\
(0.0082)\end{array}$ & $\begin{array}{c}-0.0147^{* *} \\
(0.0066)\end{array}$ & $\begin{array}{l}-0.0099 \\
(0.0112)\end{array}$ & $\begin{array}{l}-0.0187 \\
(0.0137)\end{array}$ \\
\hline Duration & $\begin{array}{c}-0.0071^{* * *} \\
(0.0022)\end{array}$ & $\begin{array}{l}-0.0044^{* *} \\
(0.0022)\end{array}$ & $\begin{array}{l}-0.0064^{* *} \\
(0.0031)\end{array}$ & $\begin{array}{c}-0.0073^{* *} \\
(0.0027)\end{array}$ \\
\hline Duration ${ }^{2}$ & $\begin{array}{l}0.0011^{* * *} \\
(0.0003)\end{array}$ & $\begin{array}{l}0.0009^{* * *} \\
(0.0003)\end{array}$ & $\begin{array}{l}0.0013^{* *} \\
(0.0005)\end{array}$ & $\begin{array}{c}0.0010^{* * *} \\
(0.0004)\end{array}$ \\
\hline NB & $\begin{array}{l}0.0060^{* *} \\
(0.0025)\end{array}$ & $\begin{array}{l}0.0068^{* *} \\
(0.0029)\end{array}$ & $\begin{array}{l}0.0092^{* * *} \\
(0.0033)\end{array}$ & $\begin{array}{l}0.0098^{* * *} \\
(0.0031)\end{array}$ \\
\hline$N^{2}$ & $\begin{array}{c}-0.0003 \\
(0.0004)\end{array}$ & $\begin{array}{l}-0.0006 \\
(0.0005)\end{array}$ & $\begin{array}{c}-0.0012^{* *} \\
(0.0005)\end{array}$ & $\begin{array}{c}-0.0011^{* * *} \\
(0.0003)\end{array}$ \\
\hline MP & $\begin{array}{c}0.4052^{* * *} \\
(0.1199)\end{array}$ & $\begin{array}{c}-1.0388^{* * *} \\
(0.1720) \\
\end{array}$ & $\begin{array}{c}0.1890 \\
(0.1516)\end{array}$ & $\begin{array}{c}0.5670^{* * *} \\
(0.1675)\end{array}$ \\
\hline $\mathrm{R}^{2}$ & 0.147 & 0.095 & 0.087 & 0.154 \\
\hline$\chi^{2}$ & $424.29^{* * *}$ & $339.08^{* * *}$ & $159.10^{* * *}$ & $313.01^{* * *}$ \\
\hline$N$ & 9,871 & 9,593 & 5,611 & 5,889 \\
\hline
\end{tabular}

Note: $i$ refers to a firm, $t$ refers to time. Each equation includes year and industry dummy variables. Robust standard errors are reported in parentheses. ${ }^{*} p<0.10,{ }^{* *} p<0.05,{ }^{* * *} p<0.01$.

Cash is the ratio of cash to net assets, where net assets are defined as total assets excluding cash. Net assets are defined as total assets minus cash. NWC is constructed as the ratio of net working capital minus cash to net assets. Size is the natural logarithm of net assets. Growth is defined as the growth of a company's sales. CF is constructed as cash flow divided by net assets. EXTurn is the ratio of export sales to net assets. Leverage is total debt over net assets. DM is the share of long-term debt in a company's total debt. BC is the share of bank loans in a company's total debt. STBC is the share of short-term bank debt in a company's total debt. Duration is the length of a firm's relationship with its main bank in years. NB is the number of banks with which a firm works. 
Table 11. Corporate Cash Holdings and Bank Relationships: Do Banks Restrict Agency Conflicts?

\begin{tabular}{|c|c|c|c|c|}
\hline \multirow{3}{*}{ Cash } & \multicolumn{2}{|c|}{ Agency Conflicts } & \multicolumn{2}{|c|}{ No Agency Conflicts } \\
\hline & High Cash & Low Growth & Low Cash & High Growth \\
\hline & (1) & $(2)$ & (3) & (4) \\
\hline NWC & $\begin{array}{c}-0.0382^{* * *} \\
(0.0126)\end{array}$ & $\begin{array}{c}-0.0107 \\
(0.0087)\end{array}$ & $\begin{array}{c}-0.0000 \\
(0.0005)\end{array}$ & $\begin{array}{c}-0.0261^{* *} \\
(0.0112)\end{array}$ \\
\hline Size & $\begin{array}{c}-0.0481^{* * *} \\
(0.0051)\end{array}$ & $\begin{array}{c}-0.0200^{* * *} \\
(0.0037)\end{array}$ & $\begin{array}{c}-0.0002 \\
(0.0002)\end{array}$ & $\begin{array}{c}-0.0316^{* * *} \\
(0.0049)\end{array}$ \\
\hline Growth & $\begin{array}{l}0.0072^{* *} \\
(0.0035)\end{array}$ & $\begin{array}{l}0.0222^{* * *} \\
(0.0052)\end{array}$ & $\begin{array}{l}0.0007^{* * *} \\
(0.0002)\end{array}$ & $\begin{array}{l}-0.0006 \\
(0.0043)\end{array}$ \\
\hline EXTurn & $\begin{array}{l}0.1904^{* * *} \\
(0.0553)\end{array}$ & $\begin{array}{l}0.2455^{* * *} \\
(0.0409)\end{array}$ & $\begin{array}{l}0.0049^{* *} \\
(0.0024)\end{array}$ & $\begin{array}{l}0.1626^{* *} \\
(0.0684)\end{array}$ \\
\hline CF & $\begin{array}{l}0.0555^{* * *} \\
(0.0073)\end{array}$ & $\begin{array}{c}0.0325^{* * *} \\
(0.0056)\end{array}$ & $\begin{array}{l}0.0007^{* *} \\
(0.0003)\end{array}$ & $\begin{array}{l}0.0589^{* * *} \\
(0.0099)\end{array}$ \\
\hline Leverage & $\begin{array}{c}0.0638^{* * *} \\
(0.0128)\end{array}$ & $\begin{array}{l}0.0262^{* * *} \\
(0.0081)\end{array}$ & $\begin{array}{c}-0.0005 \\
(0.0005)\end{array}$ & $\begin{array}{l}0.0458^{* * *} \\
(0.0116)\end{array}$ \\
\hline DM & $\begin{array}{c}0.0084 \\
(0.0101)\end{array}$ & $\begin{array}{c}0.0031 \\
(0.0067)\end{array}$ & $\begin{array}{c}-0.0004 \\
(0.0005)\end{array}$ & $\begin{array}{l}0.0245^{* *} \\
(0.0111)\end{array}$ \\
\hline$B C$ & $\begin{array}{c}-0.0271^{* *} \\
(0.0120)\end{array}$ & $\begin{array}{l}-0.0132^{*} \\
(0.0073)\end{array}$ & $\begin{array}{c}-0.0011^{* *} \\
(0.0005)\end{array}$ & $\begin{array}{l}-0.0066 \\
(0.0127)\end{array}$ \\
\hline Duration & $\begin{array}{c}-0.0063^{* *} \\
(0.0031)\end{array}$ & $\begin{array}{c}-0.0075^{* * *} \\
(0.0022)\end{array}$ & $\begin{array}{c}-0.0002 \\
(0.0002)\end{array}$ & $\begin{array}{c}-0.0051 \\
(0.0030)\end{array}$ \\
\hline Duration ${ }^{2}$ & $\begin{array}{l}0.0011^{* * *} \\
(0.0004)\end{array}$ & $\begin{array}{l}0.0011^{* * *} \\
(0.0003)\end{array}$ & $\begin{array}{c}0.0000 \\
(0.0000)\end{array}$ & $\begin{array}{l}0.0010^{* *} \\
(0.0004)\end{array}$ \\
\hline NB & $\begin{array}{l}0.0113^{* * *} \\
(0.0034)\end{array}$ & $\begin{array}{l}0.0092^{* * *} \\
(0.0033)\end{array}$ & $\begin{array}{c}0.0000 \\
(0.0003)\end{array}$ & $\begin{array}{c}0.0029 \\
(0.0036)\end{array}$ \\
\hline $\mathrm{NB}^{2}$ & $\begin{array}{c}-0.0009^{* *} \\
(0.0004)\end{array}$ & $\begin{array}{l}-0.0010^{*} \\
(0.0006)\end{array}$ & $\begin{array}{c}0.0000 \\
(0.0000)\end{array}$ & $\begin{array}{c}-0.0000 \\
(0.0006)\end{array}$ \\
\hline MP & $\begin{array}{c}0.7641^{* * *} \\
(0.1698)\end{array}$ & $\begin{array}{l}0.3428^{* *} \\
(0.1339)\end{array}$ & $\begin{array}{c}0.0831^{* * *} \\
(0.0109)\end{array}$ & $\begin{array}{l}0.5807^{* * *} \\
(0.1739)\end{array}$ \\
\hline $\mathrm{R}^{2}$ & 0.192 & 0.096 & 0.143 & 0.166 \\
\hline$\chi^{2}$ & $436.77^{* * *}$ & $277.86^{* * *}$ & $95.20^{* * *}$ & $262.42^{* * *}$ \\
\hline $\mathrm{N}$ & 8,015 & 8,887 & 7,465 & 6,595 \\
\hline
\end{tabular}

Note: $i$ refers to a firm, $t$ refers to time. Each equation includes year and industry dummy variables. Robust standard errors are reported in parentheses. ${ }^{*} p<0.10,{ }^{* *} p<0.05,{ }^{* * *} p<0.01$.

Cash is the ratio of cash to net assets, where net assets are defined as total assets excluding cash. Net assets are defined as total assets minus cash. NWC is constructed as the ratio of net working capital minus cash to net assets. Size is the natural logarithm of net assets. Growth is defined as the growth of a company's sales. CF is constructed as cash flow divided by net assets. EXTurn is the ratio of export sales to net assets. Leverage is total debt over net assets. $D M$ is the share of long-term debt in a company's total debt. $B C$ is the share of bank loans in a company's total debt. STBC is the share of short-term bank debt in a company's total debt. Duration is the length of a firm's relationship with its main bank in years. NB is the number of banks with which a firm works. 